JEL Classification: G1

Keywords: ex-dividend days, tax-clientele hypothesis, random coefficient model, tax neutrality

\title{
Ex-Dividend Day Returns when Dividend and Capital Gains are Taxed at the Same Rate*
}

\author{
Josep GARCÍA BLANDÓN (corresponding author) \\ Mònica MARTÍNEZ BLASCO \\ both authors: Department of Economics and Finance, Facultat \\ d'Economia, IQS, Universitat Ramon Llull \\ Josep ARGILES BOSCH - Department of Accounting, Facultat d'Economia i Empresa, \\ Universitat de Barcelona
}

Abstract

Due to the overwhelming international evidence that stock prices drop by less than the dividend paid on ex-dividend days, the ex-dividend day anomaly is considered a stylized fact. Two main approaches have emerged to explain this empirical regularity: the tax-clientele hypothesis and the microstructure of financial markets. Although the most widely accepted explanation for this fact relies on taxes, the ex-dividend day anomaly has been reported even in countries where neither dividends nor capital gains are taxed. The 2006 tax reform in Spain established the same tax rate for dividends and capital gains. This paper investigates stock returns on ex-dividend days in the Spanish stock market after the 2006 tax reform using a random coefficient model. Contrary to previous research, we do not observe an ex-dividend day anomaly. Unlike previous investigations, which are mostly concerned with suggesting explanations as to why this anomaly has occurred, we are in the somewhat strange position of discussing why this anomaly has not occurred. Our findings are robust across companies and stock dividend yields, thus supporting a tax-based explanation for the ex-dividend day anomaly.

\section{Introduction}

Under perfect capital markets, the price of a share should drop by exactly the dividend per share paid on ex-dividend days. Nevertheless, researchers consistently report that prices fall by less than the dividend per share paid. The results are similar across countries and do not depend on the period investigated. This behavior constitutes an empirical regularity of stock returns that has been defined as the ex-dividend day anomaly. In a pioneer investigation with a small sample of companies quoted in the New York Stock Exchange, Campbell and Beranek (1955) reported that stock prices adjusted by less than the dividend paid. They observed that prices dropped on average by $90 \%$ of the dividend paid on ex-dividend dates. The authors, however, did not offer any explanation for this anomalous behavior. Later, Elton and Gruber (1970) proposed a tax-clientele explanation for their similar finding that stock prices dropped on average by $77.7 \%$ of the dividend paid. The authors suggested that, since dividends were usually taxed at higher rates than capital gains, the drop of the stock price should be smaller than the dividend paid to make investors indifferent between selling the stock cum-dividend and holding the stock, obtaining the dividend, and selling the stock ex-dividend. The greater the difference between dividends and capital gains tax rates, the smaller the price drop should be. In addition, the authors found that as the stock dividend yield increased, so did the price adjustment expressed as a percentage of the dividend per share. Such behavior supported their proposed tax-

\footnotetext{
${ }^{*}$ The authors would like to thank two anonymous referees for their comments and suggestions.
} 
-clientele hypothesis: since those investors with relatively high tax rates would prefer to invest in low dividend yield stocks, these stocks should show a stronger tax effect than high yield ones, and therefore smaller price adjustments.

Following Elton and Gruber (1970), many papers have carried out similar investigations in stock markets worldwide, most of them supporting the tax-clientele hypothesis for the reported less than one hundred percent price adjustment. Among these papers, we can mention Poterba and Summers (1984), Robin (1991), Graham et al. (2003), Zang et al. (2008), Amromim et al. (2008), and, more recently, Witworth and Rao (2010) for the United States; Athanassakos (1996) for Canada; Hayashi and Jagannathan (1990) for Japan; Poterba and Summers (1985) for the United Kingdom; and Green and Rydqvist (1999) for the Swedish lottery bond market. Nevertheless, the fact that the ex-dividend day anomaly has been reported in countries where neither dividends nor capital gains are taxed (Frank and Jagannathan, 1998, in Hong Kong; Milonas and Travlos, 2001, in Greece; and Yahyaee et al., 2008, in Oman) has cast doubt on the tax-clientele hypothesis and encouraged a search for alternative explanations. Nevertheless, Miller and Scholes (1982) warned about the potential information-induced biases caused by dividend announcements when ex-dividend days and announcement days both occur in the same period for which returns are computed.

Before the somewhat surprising results of Frank and Jagannathan (1998), the behavior of short-term traders already provided the most accepted set of alternative explanations to the tax-clientele hypothesis for the ex-dividend day anomaly. In an influential paper, Kalay (1982) posed the so-called "short-term trading hypothesis." Following the author, even if dividends and capital gains were taxed at the same rate, we could observe less than one hundred percent price adjustments on ex-dividend dates if transaction costs were considered. If dividends and capital gains were taxed at the same rate and no transaction costs existed, stock prices should drop by the amount of the dividend paid. On the other hand, under extremely high transaction costs, the price behavior would be determined only by long-term investors (as implicitly assumed by Elton and Gruber, 1970). Finally, under moderate transaction costs, the price adjustment could be higher or lower than one without implying arbitrage opportunities for short-term traders. Although Kalay's proposal is not contradictory with the tax-clientele hypothesis, it would explain situations of partial price adjustment to dividend payments without requiring different tax rates for dividends and capital gains. The relationship between ex-dividend returns and transaction costs reported by Karpoff and Walking (1988), and the presence in the market of short-term traders observed by Lakonishok and Vermaelen (1986) and Dasilas (2009), would support the short-term trading hypothesis.

After taxes and short-term trading, the microstructure of stock markets constitutes the third approach to explaining the ex-dividend day anomaly. Within this line, Bali and Hite (1998) posed price discreteness. They argued that, since long-term investors are averse to receiving dividends because of taxes and transaction costs, they value a $\$ 1$ dividend at less than $\$ 1$. Their model pointed out that these investors would never be willing to pay more for a dividend than its value, showing that the equilibrium ex-day price drop would be the amount of the dividend rounded to the next smaller tick. Nevertheless, the results by Graham et al. (2003), Jakob and Ma (2004), and Cloyd et al. (2006) did not support the price discreteness hypothesis. Within 
the market microstructure approach, Frank and Jagannathan (1998) argued that because the collection and reinvestment of dividends was annoying, small investors would hardly buy securities immediately before ex-dividend days, but rather would do so afterwards. Thus, those investors who have already decided to buy a dividend-paying stock will postpone the operation until the ex-dividend date. In the same way, those investors who want to sell a stock will do so before this date. Accordingly, most transactions will occur at the bid price before the ex-dividend date and at the ask price later. As a result, stock prices will drop by less than the dividend paid. Kadapakkam's (2000) results reporting ex-dividend price drops near one after the introduction of electronic settlement in Hong Kong support Frank and Jagannathan's hypothesis. More recently, Jakob and Ma (2004) find that, contrary to Bali and Hite's hypothesis, after eliminating price discreteness the ex-dividend day anomaly strengthens. They also report that around ex-dividend dates bid prices fell by more than ask prices, supporting Frank and Jagannathan's hypothesis.

More than thirty years ago, Black (1976) acknowledged that the harder we looked at the dividend picture, the more it seemed like a puzzle. In spite of the numerous papers that have investigated the issue, three decades later Bhattacharyya (2007, p. 4) states: "Despite decades of study, we have yet to completely understand the factors that influence dividend policy and the manner in which these factors interact." Our paper investigates the ex-dividend day anomaly in the Spanish stock market after the 2006 tax reform. It contributes to the extant literature in various ways. Firstly, our period of investigation includes a homogeneous neutral tax regime for dividends and capital gains, therefore allowing for a direct test of the tax-clientele hypothesis. Since dividends and capital gains have been and still are usually taxed at different rates worldwide, papers investigating the issue under tax neutrality are relatively scarce. Secondly, unlike most previous investigations using the traditional Brown and Warner (1980) event studies methodology, we propose a random coefficient model with panel data observations. The advantages of this approach will be discussed in Section 3. Finally, contrary to the well-established body of empirical research, including previous investigations available for the Spanish market, we do not find the ex-dividend day anomaly in the Spanish stock market. Nevertheless, the fact that previous evidence refers to periods where capital gains enjoyed important tax advantages, emphasizes the importance of taxes for explaining the ex-dividend day anomaly.

The remainder of the paper is as follows. Section 2 summarizes the Spanish tax system for dividends and capital gains after the 2006 tax reform. In Section 3, we present our proposed methodology and our sample and dataset. The results are reported and discussed in Section 4. Finally, the last section presents our main conclusions.

\section{Spanish Taxation of Dividends and Capital Gains}

The last reform of the Spanish tax system for dividends and capital gains was enacted in Ley 35/2006, de 28 de noviembre. Its main purpose was to minimize tax-induced distortions of investment decisions. Accordingly, investment returns after taxes should preserve the pre-tax scheme. Under the new tax system, dividends and capital gains are taxed at a fixed $18 \%$ rate at the Impuesto sobre la Renta de las Per- 
sonas Físicas (IRPF), the main personal tax in Spain. Before the reform, capital gains generated in periods longer than one year were taxed at a fixed $15 \%$ rate, while capital gains generated in a one-year period or less were taxed at the investor marginal tax rate. On the other hand, dividends were taxed at the investor marginal tax rate, although there was a deduction for double taxation consisting in $40 \%$ of the dividend received multiplied by 1.4 . After the reform, this deduction was substituted by a linear exemption of the first $€ 1,500$ of dividends. Thus, wealthy investors with big portfolios currently enjoy lower benefits for double taxation compensation than small investors. In the current situation, for investors already receiving more than $€ 1,500$ in dividends, the marginal $€ 1$ return will have the same $€ 0.18$ tax impact independently of whether it is obtained as dividends or capital gains, with the obvious difference that dividends are subject to a withholding tax. On the other hand, for those investors receiving less than $€ 1,500$ in dividends, the marginal $€ 1$ return will have no tax impact if it is obtained as dividends and a $€ 0.18$ impact if it is obtained as capital gains.

In addition to the IRPF, corporations subject to the Impuesto sobre el Beneficio de las Sociedades (IS) enjoy deductions to compensate them for the double taxation of dividends. These are generally established as $50 \%$ of the dividends received, but can reach $100 \%$ under certain conditions. In the last situation, the double taxation of dividends would be completely eliminated. Although the 2006 Spanish tax reform modified the IS by lowering the general tax rate from $35 \%$ to $30 \%$, it does not affect the deductions for double taxation of dividends.

Therefore, although the reform has increased the neutrality of the tax system in the firm's dividend policy, those investors receiving dividends of less than $€ 1,500$, as well as corporations, will probably prefer dividends over capital gains, while the rest of investors will probably prefer capital gains.

Next, we discuss the empirical evidence available for the Spanish case prior to the 2006 reform. From a general perspective, De Andrés et al. (2001) discuss the distortions in stock prices induced by tax reforms in Spain. Santesmases (1982), Ruiz and Espitia (1996), and Lechón et al. (1998) investigated the periods 1978-80, 1980-92, and 1994-95, respectively. In all three cases, the authors report less than one hundred percent price adjustments. The authors explain this result in terms of the tax advantage of capital gains compared with dividends that prevailed in their periods of investigation. According to Carbajo (1991), the Spanish tax system had traditionally encouraged capital gains over dividends. This was a result of the non-existence of withholding taxes for capital gains, which favored situations of fraud, and also of unlimited compensation of capital losses with ordinary income. The latter was particularly appealing for high-income individuals subject to high marginal tax rates. This situation continued throughout the 1990s. As an example, until the 1998 tax reform, capital gains on quoted stocks generated in at least five years were tax exempt in the IRPF. Therefore, in previous research of the Spanish stock market, the tax disadvantage of dividends compared with capital gains encouraged an ex-dividend day anomaly consisting of positive abnormal returns on ex-dividend days.

\section{Methodology}

In subsections 3.1 and 3.2 we present our proposed model and the sample and dataset used in the investigation, respectively. 


\subsection{Model}

The dominant and almost exclusive approach to investigating the ex-dividend day anomaly follows the classical Brown and Warner (1980) event study methodology, with abnormal returns defined as:

$$
A R_{j t}=R_{j t}-\left(\alpha_{j}+\beta_{j} R_{m t}\right)
$$

where $A R_{j t}$ is the abnormal return on security $j$ on day $t ; R_{j t}$ and $R_{m t}$ are the returns on security $j$ and a weighted stock market index, respectively, on day $t$; and $\alpha_{j}$ and $\beta_{j}$ are estimated for firm $j$ using the market model.

After estimating the daily average abnormal returns for each firm in the sample, the average abnormal return on day $t$ for the whole sample is calculated as:

$$
\overline{A R}_{t}=\frac{1}{N} \sum_{i=1}^{N} A R_{i t}
$$

Average abnormal returns are calculated for each day of the event window, a period around the ex-dividend day, and finally the significance level of the average abnormal return on the day of the event is tested.

In a comprehensive methodological paper, Kothary and Warner (2007, p. 8) stated: "Even the most cursory perusal of event studies done over the past 30 years reveals a striking fact: the basic statistical format of event studies has not changed over time [...] The key focus is still on measuring the sample securities' mean and cumulative mean abnormal return around the time of an event." The authors highlighted various potential problems associated with this methodology, some of them related to the assumptions concerning the statistical properties of the abnormal return measures.

In this paper, we investigate the ex-dividend day anomaly from a different approach. We propose a market model with three dummy variables accounting for dividend payments, as defined by equation (3):

$$
R_{j t}=\alpha+\beta R_{m t}+\gamma D_{j t}+\eta D_{j t-1}+\theta D_{j t+1}+\varepsilon_{j t}
$$

As noted by MacKinlay (1997), although other multifactor models have been proposed, generally the gains from employing multifactor models are limited. The reason for these limited gains is the empirical fact that the marginal explanatory power of additional factors to the market factor is small. Consistently with the approach usually followed in the literature, the effects of other factors in the ex-dividend day anomaly, such as the dividend yield, will be addressed by splitting the sample into subsamples formed according to the factor whose influence we want to analyze.

Our dataset has both a cross-sectional and a temporal dimension. In this case, the estimation using panel data models offers potentially important advantages over the traditional pool regression estimation, which ignores the panel data nature of the observation and thus the heterogeneity across panel units. One of the crucial issues within panel data analysis is the way in which differences in behavior across individuals and/or time periods not captured by the explanatory variables should be 
modeled. The model represented by equation (3) attributes the heterogeneity across individuals and/or over time to omitted variables that can be individually time-invariant (variables with different values for different individuals but constant over time for any given individual) and/or period individual-invariant (variables that are constant for all the individuals in any given period but that change over time). The different families of panel data models differ in the way they treat heterogeneity. On the one hand, fixed effects models allow each cross-sectional unit to have its own constant term while the slope estimates are constrained across units, allowing the unobserved individual effects to be correlated with the independent variables. On the other hand, if the individual effects are uncorrelated with the included variables, random effects models are more suitable since they assume the individual specific constant term to be randomly distributed across cross-sectional units (Greene, 2007). However, both fixed and random effects models will assume no parameter variations across firms, that is, the same slopes for all the companies in the sample. Nevertheless, in the model expressed by equation (3) the assumption of constant slopes across individuals seems unrealistic since it requires that all the companies in the sample show the same level of systemic risk, therefore implying their returns will have the same sensitivity to market movements. The fact that our dataset is formed by companies belonging to different economic sectors, with different cost structures, sizes, debt levels, etc., makes it difficult to assume that all the companies in the sample will show the same sensitivity to market movements. Therefore, fixed as well as random effects models, both assuming no parameter variation across firms, would not be appropriate in this case. However, random coefficient models do not assume a constant coefficient vector relating the dependent and independent variables, since they treat the parameters as a realization, for each individual, of a stochastic process. Following Swamy and Tavlas (2001), the random coefficient model relaxes not only the constant coefficient assumption, but also three other strong assumptions usually made by econometric researchers: 1 . the true functional form of the relationship between the dependent and independent variables is known; 2. omitted variables, measured by the error term, have zero mean and are independent of the explanatory variables, and 3. there are no measurement errors.

The model to be finally estimated is given by expression (4).

$$
R_{j t}=\alpha+\beta_{j} R_{m t}+\gamma_{j} D_{j t}+\eta_{j} D_{j t-1}+\theta_{j} D_{j t+1}+\varepsilon_{j t}
$$

The difference between expressions (3) and (4) is that the latter allows parameter variation across firms. In order to check the stability of the results across our sample of stocks, after the estimation of equation (4) for the whole sample using the random coefficient model the model will be re-estimated using the seemingly unrelated regression equations (SURE) estimation method. Following Greene (2007), the SURE approach is particularly suitable for estimating our model since it allows us to account for correlation of the error term across securities.

As we discussed in the previous section, Elton and Gruber (1970) and other researchers since them have reported that high dividend yield stocks tend to show higher price adjustment than their low dividend counterparts. Accordingly, we classified the stocks in our sample in quartiles according to dividend yield. Next, equation (4) will be re-estimated for each dividend yield quartile. 
Table 1 Descriptive Statistics of Stocks And Market Returns

\begin{tabular}{lcccc}
\hline Variable & Mean & Std. Dev. & Min. & Max. \\
\hline$R_{m t}$ & -0.0006 & 0.0192 & -0.0959 & 0.1012 \\
$R_{j t}$ & -0.0006 & 0.0268 & -0.2524 & 0.2345 \\
\hline
\end{tabular}

\subsection{Sample and Dataset}

Our stock sample is formed by the cash dividend paying constituents of the IBEX-35 index at the end of the research period. With the exception of Iberdrola Renovables, all the IBEX-35 constituents paid cash dividends during the period of investigation. Therefore, our dataset is formed by 34 companies. These companies made 187 cash dividend payments during the observation period.

Table 1 presents some descriptive statistics about the continuous variables in equation (4). The reported negative average returns are due to the fall of stock markets worldwide caused by the subprime mortgage crisis.

As a first step to account for abnormal returns on ex-dividend days, we performed the non-parametric Mann-Whitney test of differences of medians to the variable $R_{j t}$. This test is almost identical to the $t$-test of differences of means, but does not assume a normal distribution. According to the results of the Mann-Whitney test, we do not observe a significant difference between returns on ex-dividend days compared to ordinary days.

\section{Results}

The Mann-Whitney test suggested that ex-dividend day returns were not different from the returns on other days. The estimation of the proposed model confirms this preliminary result. Equation (4) was estimated using Swamy's random coefficient model with generalized least squares. Table 2 shows the estimates of the model with values in parentheses. The table also provides a significance Chi-square test for the whole model. As discussed in Section 3, we expect stocks in our sample to show different sensitivities to the explanatory variables in the model. Therefore, once the random coefficient model was estimated, we tested whether the panel-specific coefficients differ significantly across panels. Following Poi (2003), in Swamy's random-coefficients model, under the null hypothesis $\left(H_{0}\right)$,

$$
H_{0}=\beta_{1}=\beta_{2}=\ldots=\beta_{p}
$$

the test statistic is distributed as a Chi-Square with $k(p-1)$ degrees of freedom, with $p$ being the number of panels and $k$ the number of parameters specific to panel $i$. As can be seen in Table 3, the null hypothesis $\left(H_{0}\right)$ is rejected, thus supporting our choice to use a random coefficient model.

As shown by Table 2, the only explanatory variable with an associated coefficient significantly different from zero is $R_{m t}$. None of the three dummy variables accounting for dividend payments shows associated coefficients statistically significant at the required levels. Therefore, stock price adjustments on ex-dividend days are not significantly different from the dividend paid. This result indicates that the ex-dividend day anomaly, widely documented across stock markets worldwide, is not 
Table 2 Estimates of Equation (4)

\begin{tabular}{lcc}
\hline Variable & Coefficient & $\boldsymbol{P}$-values \\
\hline Constant & -0.00003 & 0.866 \\
$R_{m t}$ & 0.94684 & 0.000 \\
$D_{j t}$ & 0.00147 & 0.560 \\
$D_{j t-1}$ & 0.00147 & 0.432 \\
$D_{j t+1}$ & -0.00371 & 0.075 \\
\hline$N$ & 20989 & \\
Chi-square & $464.24^{*}$ & \\
\hline
\end{tabular}

Table 3 Test of Parameter Constancy Across Firms

\begin{tabular}{lcc}
\hline & Full sample & Significance level \\
\hline Chi-Square & 2144.83 & 0.00000 \\
\hline
\end{tabular}

observed in the Spanish stock market after the 2006 tax reform. Our result, is somewhat surprising given the overwhelming empirical evidence supporting less than perfect price adjustment on ex-dividend days. As we discussed in section 2, prior research in the Spanish stock market has often reported the ex-dividend day anomaly. Accordingly, if the different taxation of dividends and capital gains were the cause of the ex-dividend day anomaly, in the current situation of tax neutrality after the 2006 reform we should not expect such an anomaly to occur. Therefore, our findings are consistent with previous evidence available for the Spanish market, supporting a tax explanation for the ex-dividend day anomaly.

As discussed in Section 2, although the main purpose of the Spanish tax reform in 2006 was to achieve tax neutrality, the tax exemption for the first $€ 1,500$ in dividends for individual investors, the fact that dividends are subject to withholding taxes, and the deductions for double dividend taxation for corporations, make this neutrality imperfect. Naranjo et al. (2000) warned against the assumption that there is one investor tax clientele that determines the ex-dividend day return, suggesting a tax heterogeneity explanation for ex-dividend day returns. Since market participants show different tax profiles, the ex-day return may more properly be viewed as a result of the interaction between investors with different tax-induced valuations on dividends and capital gains. Accordingly, in the Spanish case those investors with small portfolios should show a preference for dividends over capital gains (since the first $€ 1,500$ in dividends is tax exempt, while this is not the case for capital gains). Corporations, on the other hand, should also show a preference for dividends over capital gains, since they enjoy important tax deductions to avoid the double taxation of dividends. Finally, other investors should prefer capital gains to dividends as only dividends are subject to withholding taxes. Depending on which group of investors prevails, we could observe ex-dividend day returns to be abnormally positive, negative or insignificant. Therefore, our results could also be interpreted in this sense. There are different groups of investors with different preferences for dividends and capital gains, but since none of them clearly prevails, the result we finally observe is that returns on ex-dividend days are not significantly different from returns on other days. However, further research is needed, including the examination of trading volumes and trans- 
Table 4 Estimates of the SURE Equations

\begin{tabular}{|c|c|c|c|c|c|c|}
\hline Company & Constant & $R_{m t}$ & $D_{j t}$ & $D_{j t-1}$ & $D_{j t+1}$ & $R^{2}$ \\
\hline Abertis & -0.00021 & 0.82 & 0.0052 & 0.0090 & -0.0002 & 0.62 \\
\hline ACS & 0.00041 & 0.82 & -0.0114 & 0.0097 & -0.0006 & 0.59 \\
\hline Bankinter & 0.00035 & 0.94 & 0.0127 & -0.0074 & -0.0044 & 0.42 \\
\hline Abengoa & 0.00003 & 1.08 & -0.0133 & 0.0113 & -0.0179 & 0.48 \\
\hline BBVA & -0.00031 & 1.30 & 0.0048 & $0.0060^{*}$ & -0.0044 & 0.87 \\
\hline Acciona & -0.00001 & 1.22 & 0.0005 & 0.0017 & 0.0021 & 0.55 \\
\hline B. Sab. & -0.00039 & 0.75 & -0.0012 & -0.0017 & 0.0009 & 0.57 \\
\hline B. Pop. & 0.00039 & 1.23 & 0.0015 & 0.0029 & -0.0024 & 0.68 \\
\hline Acerinox & -0.00013 & 0.88 & 0.0022 & -0.0045 & -0.0032 & 0.48 \\
\hline Banesto & -0.00051 & 0.88 & -0.0006 & -0.0023 & -0.0012 & 0.57 \\
\hline Santander & 0.00032 & 1.35 & 0.0020 & 0.0012 & -0.0039 & 0.84 \\
\hline Enagas & 0.00021 & 0.55 & -0.0007 & -0.0007 & -0.0020 & 0.31 \\
\hline Gamesa & 0.00019 & 1.41 & 0.0004 & 0.0043 & 0.0070 & 0.56 \\
\hline BME & 0.00051 & 0.85 & -0.0016 & -0.0121 & -0.0047 & 0.41 \\
\hline Endesa & -0.00015 & 0.58 & -0.0039 & 0.0043 & -0.0001 & 0.30 \\
\hline Gas Nat. & -0.00067 & 0.84 & 0.0016 & 0.0116 & 0.0045 & 0.41 \\
\hline Ferrovial & -0.00081 & 1.25 & -0.0064 & -0.0018 & -0.0014 & 0.57 \\
\hline Grifols & 0.00053 & 0.52 & 0.0177 & 0.0020 & 0.0149 & 0.18 \\
\hline Criteria & -0.00021 & 0.86 & $0.0193^{*}$ & 0.0007 & -0.0038 & 0.55 \\
\hline FCC & -0.00068 & 0.92 & -0.0048 & -0.0042 & -0.0053 & 0.57 \\
\hline Iberdrola & 0.00014 & 1.16 & -0.0036 & 0.0075 & -0.0086 & 0.70 \\
\hline Mapfre & 0.00020 & 0.92 & -0.0019 & 0.0015 & 0.0029 & 0.40 \\
\hline Repsol & 0.00003 & 1.03 & -0.0070 & 0.0020 & -0.0046 & 0.71 \\
\hline Iberia & -0.00009 & 0.77 & -0.0093 & 0.0067 & -0.0263 & 0.23 \\
\hline $\mathrm{OHL}$ & -0.00012 & 1.05 & 0.0110 & -0.0028 & -0.0043 & 0.44 \\
\hline Sacyr & -0.00152 & 1.14 & -0.0010 & 0.0041 & -0.0085 & 0.37 \\
\hline Inditex & 0.00028 & 0.86 & 0.0133 & -0.0031 & 0.0082 & 0.46 \\
\hline Red Elec. & 0.00067 & 0.55 & -0.0001 & -0.0027 & $-0.0186^{* *}$ & 0.30 \\
\hline Técnicas $\mathrm{R}$. & 0.00067 & 1.01 & 0.0123 & 0.0181 & 0.0026 & 0.39 \\
\hline Indra & 0.00015 & 0.55 & 0.0029 & 0.0101 & -0.0084 & 0.33 \\
\hline Telecinco & -0.00065 & 0.82 & $-0.0375^{\star *}$ & -0.0101 & -0.0182 & 0.38 \\
\hline Telefónica & 0.00045 & 0.81 & $0.0097^{*}$ & $0.0104^{* *}$ & 0.0039 & 0.73 \\
\hline Cintra & -0.00102 & 1.05 & $0.0379^{* *}$ & -0.0113 & -0.0201 & 0.53 \\
\hline Arcelor M. & 0.00092 & 1.49 & -0.0052 & -0.0153 & $-0.0224^{*}$ & 0.47 \\
\hline
\end{tabular}

Notes: *Significant at a $5 \%$ level.

${ }^{* *}$ Significant at a $1 \%$ level.

action costs by investor type, to more exhaustively support the tax heterogeneity hypothesis in the Spanish stock market.

To assess the robustness of our results to outlier values, we re-estimated equation (4) after excluding $0.5 \%$ of the observations with the highest absolute estimation errors. The results, not reported, remain largely unchanged.

We re-estimated our proposed model using the SURE approach. In Table 4 we show the coefficients of the explanatory variables and the coefficient of determination $R^{2}$. The coefficient associated with $R_{m t}$ is statistically significant at the $1 \%$ level 
Table 5 Estimates of Equation (4) by Dividend Yield Quartile

\begin{tabular}{lcccc}
\hline Variable & $\mathbf{1}^{\text {st }}$ Quartile & $\mathbf{2}^{\text {nd }}$ Quartile & $\mathbf{3}^{\text {rd }}$ Quartile & $\mathbf{4}^{\text {th }}$ Quartile \\
\hline \multirow{2}{*}{ Constant } & -0.0000972 & -0.0001724 & 0.0001041 & 0.000033 \\
& $(-0.36)$ & $(-0.62)$ & $(0.35)$ & $(0.09)$ \\
$R_{m t}$ & $0.9846655^{* *}$ & $0.8652194^{* *}$ & $0.8520237^{* *}$ & $1.06913^{* *}$ \\
& $(11.21)$ & $(24.28)$ & $(8.38)$ & $(10.73)$ \\
$D_{j t}$ & 0.0014751 & -0.0017486 & 0.002789 & 0.0023614 \\
& $(0.22)$ & $(-0.40)$ & $(0.77)$ & $(0.50)$ \\
$D_{j t-1}$ & 0.0000326 & 0.0027121 & 0.0039642 & -0.0018247 \\
& $(0.001)$ & $(0.81)$ & $(0.96)$ & $(-0.43)$ \\
$D_{j t+1}$ & -0.0044389 & -0.0022474 & -0.0052932 & -0.0026003 \\
\hline$N$ & $(-1.34)$ & $(-0.51)$ & $(-1.49)$ & $(-0.48)$ \\
\hline Chi-square & 5645 & 4714 & 4998 & 5631 \\
\hline
\end{tabular}

Notes: **Significant at a $1 \%$ level.

in all 34 equations. The large variability in the estimated coefficients and $R^{2}$ values across stocks supports our decision to use a random coefficient approach. Only in 4 of the 34 companies studied do we observe ex-dividend day returns that were significantly different from returns on other days - in Criteria and Telefonica at the 5\% level, while in Telecinco and Cintra at the 1\% level. Further, the sign of the effect is positive for Criteria, Telefonica, and Cintra, while negative for Telecinco. Regarding the day before and after the ex-dividend day, we observe significant effects in only two companies for each day: BBVA and Telefonica for the day before dividend payments, and Red Electrica and Arcelor Mittal for the day after.

Following Elton and Gruber (1970), and many other researchers since, high yield stocks are expected to show stronger abnormal returns on ex-dividend dates than lower yield stocks due to a tax-clientele issue. However, under similar taxation for dividends and capital gains, we should not expect different behavior for the two types of firms. According to our results from the SURE estimation, we do not expect our findings to depend on the company payout ratio. Therefore, we split our sample into quartiles according to the stock dividend yield and re-estimated equation (4) for each quartile using a random coefficient model. The results are reported in Table 5. As expected, no ex-dividend day anomaly is observed for any of the quartiles.

\section{Conclusions}

Over the past 40 years, researchers investigating the ex-dividend day behavior of stock prices have found that prices tend to fall by less than the dividend paid. Although there is no general consensus regarding the determinants of this abnormal behavior, the anomaly itself is accepted as a stylized fact. Since we do not observe this anomaly in the Spanish stock market, we are in a somewhat ironic position. While other authors make efforts to develop theories to explain why the price only partially adjusts to dividend payments, we have to explain why this anomaly has not occurred.

Since the most widely accepted explanation of the ex-dividend day anomaly relies on taxes, major changes in national tax schemes offer important opportunities 
to advance the research into this anomaly. In the Spanish tax system, capital gains had traditionally enjoyed better treatment than dividends. Consistently with the tax-clientele hypothesis, the empirical evidence available for the Spanish stock market has supported an ex-dividend day anomaly. The 2006 tax reform, establishing the same tax rate for dividends and capital gains, offers an appealing scenario to investigate the ex-dividend day anomaly. If the cause of the reported positive abnormal returns on ex-dividend days previous to the 2006 tax reform was taxes, after the reform the ex-dividend day anomaly should disappear. Therefore, consistently with this explanation, we do not observe abnormal returns associated with ex-dividend days after the 2006 tax reform. In addition, our results are robust to the stock dividend yield.

Although, our main interest was to investigate stock returns on ex-dividend days, our model also accounts for the behavior of returns the day before and after the dividend payment in order to capture anomalous behavior around dividend payments. Consistently with the results reported for ex-dividend days, we do not observe abnormal returns the day before or after dividend payments.

A natural extension of our research would be to test our proposed model before the 2006 tax reform. Consistently with our discussion in section 3 and with previous research available for the Spanish case, we would expect to report positive abnormal returns associated with ex-dividend dates. This would allow for the assessment of the robustness of the results according to the model choice.

\section{REFERENCES}

Amromin G, Harrison P, Sharpe S (2008): How Did the 2003 Dividend Tax Cut Affect Stock Prices? Financial Management, 37:625-646.

Andres J de, Barbera M, Garbajosa M, Terceño A (2001): Incidencia de la fiscalidad de los dividendos y ganancias patrimoniales en la rentabilidad de las acciones. Revista Española de Financiación y Contabilidad, 108:455-474.

Athanassakos G (1996): Tax-induced trading volume around ex-dividend days under different tax regimes: the Canadian experience 1970-1984. Journal of Business Finance and Accounting, 23:557-584.

Bali R, Hite G (1998): Ex-dividend day stock price behaviour: Discreteness or tax-induced clienteles? Journal of Financial Economics, 47:127-159.

Bhattacharyya N (2007): Dividend policy: a review. Managerial Finance, 33(1):4-13.

Black F (1976): The dividend puzzle. Journal of Portfolio Management, 2:5-8.

Brown S, Warner J (1980): Measuring security price performance. Journal of Financial Economics, 8:205-258.

Campbell J, Beranek W (1955): Stock price behaviour on ex-dividend dates. Journal of Finance, 10: $425-429$.

Carbajo F (1991): El gravamen de las plusvalías en España a la luz de las reformas en los países de la OCDE. In: El Impuesto sobre la Renta de las Personas Físicas: pasado, presente y futuro del tributo. Instituto de Estudios Fiscales.

Cloyd C, Li O, Weaver C (2006): Ticks and tax: The effects of price discreteness and taxation on exdividend day returns. Journal of the American Taxation Association, 28(2):23-46.

Dasilas P (2009): The ex-dividend day stock price anomaly: evidence from the Greek stock market. Financial Markets and Portfolio Management, 23(1):59-91. 
Elton E, Gruber M (1970): Marginal shareholder tax rates and the clientele effect. Review of Economics and Statistics, 52:68-74.

Frank M, Jagannathan R (1998): Why do stock prices drop by less than the value of the dividend? Evidence from a country without taxes. Journal of Financial Economics, 47:161-188.

Greene W (2007): Econometric analysis. Pearson.

Graham J, Michaely R, Roberts M (2003): Do price discreteness and transactions costs affect stock returns? Comparing ex-dividend pricing before and after decimalization. Journal of Finance, 58:2613-2637.

Green R, Rydqvist K (1999): Ex-day behaviour with dividend preference and limitations to short-term arbitrage: The case of Swedish lottery bonds. Journal of Financial Economics, 53(2):145-187.

Hayashi F, Jagannathan R (1990): Ex-day behaviour of Japanese stock prices: New Insights from new methodology. Journal of the Japanese and International Economies, 4:401-427.

Jakob K, Ma T (2004): Tick size, NYSE rule 118, and ex-dividend day stock price behaviour. Journal of Financial Economics, 72:605-625.

Kalay A (1982): The ex-dividend day behaviour of stock prices: A re-examination of the clientele effect. Journal of Finance, 37:1059-1070.

Kadapakkam P (2000): Reduction of constraints on arbitrage trading and market efficiency: An examination of ex-day returns in Hong Kong after introduction of electronic settlement. Journal of Finance, 55(6):2841-2861.

Karpoff J, Walking, R (1988): Short-term trading around ex-dividend days: Additional evidence. Journal of Financial Economics, 21(2):291-298.

Kothari S, Warner J (2007): Econometrics of event studies. In: Eckbo B (Ed.): Handbook of Corporate Finance: Empirical Corporate Finance. Elsevier/North-Holland.

Lakonishok J, Vermaelen T (1986): Tax-induced trading around ex-dividend days. Journal of Financial Economics, 16(3):287-319.

Lechón P, Lobera E, Riaño C, Ruiz F (1998): Valoración de Dividendos en el Mercado Bursátil Español. Actualidad Financiera, 7:45-56.

MacKinlay A (1997): Event studies in economics and finance. Journal of Economic Literature, 35:13-39.

Milonas N, Travlos N (2001): The ex-dividend day stock price behaviour in the Athens stock exchange. EFMA 2001 Lugano Meetings

Available at: http://ssrn.com/abstract=274080 or doi:10.2139/ssrn. 274080

Miller M, Scholes M (1982): Dividends and taxes: Some empirical evidence. Journal of Political Economy, 90:1118-1141.

Naranjo A, Nimalendran M, Ryngaert M (2000): Time variation of ex-dividend day stock returns and corporate dividend capture: A re-examination. Journal of Finance, 50:2357-2372.

Poi B (2003): From the help desk: Swamy's random-coefficients model. The Stata Journal, 3(3):302-308.

Poterba J, Summers L (1985): The Economic Effects of Dividend Taxation. In: Altman E, Subramanyam M (Eds.): Recent Advances in Corporate Finance. Richard Irwin.

Poterba J, Summers L (1984): New evidence that taxes affect the valuation of dividends. Journal of Finance, 39:1397-1415.

Robin A (1991): The Impact of The 1986 Tax Reform Act on Ex-Dividend Day Returns. Financial Management, 20:60-70.

Ruiz F, Espitia M (1996): La formación de precios de las acciones alrededor del pago de dividendos en el mercado de capitales español. Revista Española de Financiación y Contabilidad, 25(86):179-198.

Santesmases M (1981): Efecto del Pago del Dividendo en el Comportamiento de las Cotizaciones de las Acciones. Económicas y Empresariales, 13:68-82. 
Swamy P, Tavlas G (2001): Random coefficient models. In: Baltagi B (Ed.): A comparison to theoretical econometrics. Oxford, Blackwell Publishers.

Whitworth J, Rao R (2010): Do tax law changes influence ex-dividend stock price behaviour? Evidence from 1926 to 2005. Financial Management, 39(1):419-445.

Yahyaee K, Pham T, Walter T (2008): Ex-dividend day behaviour in the absence of taxes and price discreteness. International Review of Finance, 8(3-4):103-123.

Zhang Y, Farrell K, Brown T (2008): Ex-dividend day price and volume: The case of 2003 dividend tax cut. National Tax Journal, 61(1):105-27. 